\title{
Serotype Detection, Molecular Characterization, and Genetic Relationship Study on Pasteurella multocide Local Isolate
}

\author{
Prihandini $\mathrm{SS}^{1}$, Noor $\mathrm{SM}^{1}$, Kusumawati $\mathrm{A}^{2}$ \\ ${ }^{1}$ Indonesian Research Center for Veterinary Science \\ ${ }^{2}$ Faculty of Veterinary, Universitas Gadjah Mada \\ E-mail: sri2suryatmiati@gmail.com
}

(received 09-04-2017; revised 08-06-2017; accepted 23-06-2017)

\begin{abstract}
ABSTRAK
Prihandini SS, Noor SM, Kusumawati A. 2017. Deteksi serotipe, karakterisasi molekuler dan studi kekerabatan genetik isolat lokal Pasteurella multocide. JITV 22(2): 91-99. DOI: http://dx.doi.org/10.14334/jitv.v22i2.1630

Pasteurella multocide merupakan bakteri penyebab penyakit ngorok atau Haemorrhagic Septicaemia (HS) di Indonesia dengan tingkat mortalitas dan morbiditas yang tinggi pada heterogenus spesies tak terkecuali sapi sebagai sumber produk hewani yang memiliki nilai ekonomis tinggi. Kompleksitas identifikasi secara konvensional dan biokimia menjadi kendala utama dalam deteksi penyakit ini terutama karena $P$. multocide memiliki lima golongan serotipe yaitu A, B, D, E dan F, meskipun serotipe B merupakan penyebab utama kasus HS di Asia termasuk Indonesia. Untuk itu perlu dilakukan suatu penelitian yang dapat mempermudah penentuan serotipe. Tujuan penelitian ini selain untuk deteksi serotipe lima isolat $P$. multocide yang berasal dari Lampung dan Kupang, juga untuk melakukan karakterisasi molekuler dan studi kekerabatan genetik dengan teknik Polymerase Chain Reaction (PCR) dan sekuensing. Setelah dilakukan PCR terhadap gen spesifik, gen kapsular, gen 16S rRNA, sekuensing dan analisis menggunakan Bioedit, BLASTn, CLUSTALW dan MEGA7.0.25, diketahui bahwa kelima isolat terbagi menjadi dua kelompok serotipe yaitu A dan B. Isolat P. multocide (kode PMc) asal Lampung memiliki homologi tinggi dengan isolat ATCC 12945, sehingga dapat digunakan sebagai kontrol positif serotipe A dalam deteksi isolat $P$. multocide lain dengan PCR. Sedangkan isolat $P$. multocide asal Kupang dapat digunakan sebagai kontrol positif serotipe B karena identik dengan $P$. multocide PMTB2.1 (CP007205.2) asal Malaysia yang diisolasi dari kerbau terinfeksi HS.
\end{abstract}

Kata Kunci: Pasteurella multocide, Ngorok, Deteksi, Polymerase Chain Reaction (PCR), Sekuensing

\section{ABSTRACT}

Prihandini SS, Noor SM, Kusumawati A. 2017. 2017. Serotype detection, molecular characterization and genetic relationship study on Pasteurella multocide local isolate. JITV 22(2): 91-99. DOI: http://dx.doi.org/10.14334/jitv.v22i2.1630

Pasteurella multocide is a bacteria that causes snoring disease or Haemorrhagic Septicaemia (HS) in Indonesia with high mortality and morbidity in heterogeneous species including cattle as a source of animal products with high economic value. The complexity of conventional and biochemical identification is a major obstacle in the detection of this disease because $P$. multocide has five serotypes A, B, D, E and F, while serotype B is the leading cause of HS cases in Asia including Indonesia. Therefore, it is necessary to conduct a research that can determine the serotype and molecular characterization and genetic study of five isolates of P. multocide from Lampung and Kupang by Polymerase Chain Reaction (PCR) technique. After PCR was performed on specific genes, capsular genes, 16S rRNA genes, sequencing and analysis using Bioedit, BLASTn, CLUSTALW and MEGA7.0.25, it was found that the five isolates were divided into two serotype groups: A and B. Isolate P. multocide (code: PMc) from Lampung is high homolog with ATCC isolate 12945, so it can be used as a positive control serotype A in the detection of other P. multocide isolates with PCR. Whereas, isolate P. multocide from Kupang can be used as positive control of serotype B because it is identical to P. multocide PMTB2.1 (CP007205.2) from Malaysia that is isolated from buffalo infected by HS.

Key Words: Pasteurella multocide, Snoring Disease, Detection, Polymerase Chain Reaction (PCR), Sequencing

\section{INTRODUCTION}

Pasteurella multocide ( $P$. multocida) is a pathogen gram-negative bacteria for livestock animals and causes specific pasteurellosis with the main symptoms: fever and respiratory disorder causing sound like snoring due to the neck swelling that extends to chest area resulting in suppression of respiratory cavity. Therefore, pasteurellosis on cattle and buffalo or Septicaemia
Epizootic (SE)/ Haemorraghic Septicaemia (HS) in Indonesia is well known as snoring disease. In addition to being acute, its high morbidity and sepsis are extremely deadly to the infected animals. HS is a mayor epizootic disease on cattle and buffalo in the developing countries with high average morbidity and mortality (El-Jakee et al. 2016). HS can acutely infect cattle or buffalo that leads to economic losses in the Southeast Asia including Indonesia. Therefore, this disease is a 
crucial disease from the economy point of view (Moustafa et al. 2015). The first infection in Indonesia was reported in Balaraja, Tangerang in 1884 and last several years, it was reported to extend to the South Kalimantan in 2003; South Bengkulu, South Tapanuli, Riau, Jambi and Kaur in 2005; East Nusa Tenggara and Muko-muko Bengkulu in 2006.

$P$. multocide is divided into five capsule serotypes: A, B, D, E, and F. The serotype causes HS to cattle or buffalo is serotype B:2 or Asian serotype and serotype E:2 or African serotype (Moustafa et al. 2015). $P$. multocide with Serotype A and some serotypes D capsule leads to fowl cholera in poultry (Dziva et al. 2008). P. multocide along with the Bordetella bronchiseptica causes acute atrophic rhinitis to pig related to high strain toxigenicity, because the $P$. multocide play a dominant role leading to the development of anthropic rhinitis lesi (Magyar et al. 2013; Kubatzky 2012; Shayegh et al. 2009) as well as it is related to pneumonia and septicemia diseases (De Oliveira et al. 2015). Liu et al (2017) reported that prevalence of $P$. multocide Serotype A is the most common in China before 1990 followed by serotype B and D.

Those five different $P$. multocide capsule serotypes causing the detection and differentiation processes are a different from indirect haemagglutination test developed. A conventional method to detect and diagnose Pasteurella infection on the bacterial observation uses microscopy with the staining. Moreover, isolation using in vitro on the selective medium followed by phenotypic and serology characteristic are conducted (Wilson \& Ho 2013) that takes a long time. Method of detection and differentiation of serotype $\mathrm{A}$ and $\mathrm{D}$ of $P$. mulcotide widely used in the veterinary laboratory, especially in the developing countries is a non-serology test (Arumugam et al. 2011b). Some DNA-based methods that have been developed to determine the type of molecular are PCR-based, Restriction endonuclease analysis/REA, ribotyping, colony hybridization test, Filled Alternation Gel Electrophoresis (FAGE) and Real-Time PCR (Ranjan et al. 2011). The other DNAbased methods that are also developed are DNA hybridization (Mutters et al. 1985), endonuclease restriction analysis (Kim \& Nagaraja 1990), pulsedfield gel electrophoresis (PFGE) and Capsular Polymerase Chain Reaction (PCR) (Townsend et al. 2001). The PEGE is determined as the golden standard, but it requires complicated planning and expensive equipment compared to the Capsular PCR which is simpler to be applied. Therefore, in this study, it was developed a technique of detection and differentiation of P. mulcotide using Capsular PCR which can detect capsular gen of $P$. multocide to four isolates from Lampung and one isolate from Kupang.

\section{MATERIALS AND METHODS}

\section{Bacteria isolation}

P. multocide isolate used in this study were five sample isolates from Lampung (4 isolates) and Kupang (1 isolate). Those five isolates have been re-detected morphologically and bio-chemically at Laboratory of Bacteriology, Indonesian Research Center for Veterinary Science (IRCVS), Bogor. Isolate of $P$. multocide ATCC12945 (serotype A) (Furian et al. 2014) and NCTC 11668 (serotype B) from America and IRCVS collection, respectively were used as control positive, while the Brucella $s p$ isolate as a negativecontrol.

\section{Primer}

Standard OIE primer was used to detect specific species (kmt gene) and capsular gene (hyaD-hyaC and $b c b \mathrm{D})$ to those five $P$. multocide isolates in this study. CAPA is a pair of primer to detect amplicons of the capsular gene of hyaD-hyaC and $b c b \mathrm{D}$ (serotype $\mathrm{A}$ ), while the CAPB is a pair of primer to detect $\mathrm{B} / \mathrm{bcbD}$ capsular amplicon (serotype B). Amplification of $16 \mathrm{~S}$ rRNA gene was conducted using a pair of 16S PM1 primer designed from five gene references from GenBank on online devices of Primer3Plus (http://www.bioinformatics.nl/primer3plus). Structure of nucleotide base of forward primer of 16S PM1 was 5'-AGG-CCT-TCG-GGT-TGT-AAA-GT-3 and reverse: 5'-CCA-TGC-AGC-ACC-TGT-CTC-TA3 'with the size of the product by 642 base pairs. Before the construction, specivity of primer was tested first using the same online software device (Thornton \& Basu 2011).

\section{Detection and characterizing of specific species molecular (kmt Gene) of P. multocide using PCR}

Phenotypic and bio-chemical detection of those five $P$. multocide isolates was performed. Nuclear acidbased detection was started using extraction of $P$. multocide DNA as template PCR using specific primer of KMT1T7: 5'-ATC-CGC-TAT-TTA-CCC-AGT-GG3' and KMT1SP6: 5'-GCT-GTA-AAC-GAA-CTCGCC-AC-3' (Townsend et al. 2000).

Reconstitution of $P$. multocide isolate was conducted by dissolving frozen dry isolates in the Brain Herat Infusion (BHI) then was incubated at $38^{\circ} \mathrm{C}$ for 24 hours. Isolates culture from incubation in the blood agar medium was then harvested for DNA isolation using Qiagen $®$ kit.

Concentration of isolated DNA was then measured using NanoDrop 1000 Spectrophotometer OD $_{260 / 280 \mathrm{~nm}}$ and stored in the micro tube at $20^{\circ} \mathrm{C}$ as stock template 
of each PCR reaction. The kmt gene was detected by reacting a mixture of $22.5 \mu$ l Platinum PCR SuperMix High Fidelity Invitrogen, $0.5 \mu 1$ primer KMT1T7, $0.5 \mu 1$ primer KMT1SP6, and $1.5 \mu \mathrm{l}$ DNA samples. PCR reaction was performed using these following programs: pre-denaturation (at $94^{\circ} \mathrm{C}$ for 2 minutes); denaturation (at $94^{\circ} \mathrm{C}$ for 30 seconds); annealing (at $55^{\circ} \mathrm{C}$ for 30 seconds); elongation (at $68^{\circ} \mathrm{C}$ for 30 seconds); post elongation (at $68^{\circ} \mathrm{C}$ for 1 minute). The reaction was performed for 35 cycles and then the PCR product was electrophoresed in the gel agarose $2 \%$ at 100 volt, $200 \mathrm{~mA}$ for 70 minutes and showed the tape at around 460 base pairs under UV exposure and was documented using the geldoc.

\section{Detection and characterization of capsular gene molecule of $P$. multocide using PCR}

Once the isolate in previous PCR reaction was confirmed as $P$. multocide, then further detection of the capsular serotype was performed. Mix reaction consisting of $22.5 \mu \mathrm{l}$ of Platinum PCR SuperMix High Fidelity invitrogen, $0.5 \mu \mathrm{l}$ primer of capsular forward, $0.5 \mu \mathrm{l}$ primer of capsular reverse and $1.5 \mu \mathrm{l}$ DNA samples. PCR condition and the electrophoresis on agarose gel were similar to the detection program of the kmt gene. Amplification of capsular gene of $\mathrm{A} /$ hyaDhyaC used primer of CAPA: forward 5'-TGC-CAAAAT-CGC-AGT-CAG-3' and reverse 5'-TTG-CCATCA-TTG-TCA-GTG-3' with product 1044 bp (Townsend et al. 2001). Amplification of capsular $\mathrm{B} / \mathrm{bcbD}$ gene used primer of CAPB: forward 5'- CATTTA-TCC-AAG-CTC-CAC-C-3' and reverse 5'- GCCCGA-GAG-TTT-CAA-TCC -3'with the product at around $760 \mathrm{bp}$.

\section{Detection and characterization of molecule gene $16 \mathrm{~S}$ rRNA of $P$. multocide using PCR}

Amplification of 16S rRNA gene was performed to determine the genetic relationship (Mizrahi-Man et al. 2013) of six local isolate of $P$. multocide from various countries at the GenBank. PCR reaction was performed by mixing $12.5 \mu \mathrm{l}$ Hot Star Taq, $1 \mu 1$ primer forward, 1 $\mu 1$ primer reverse, $1 \mu \mathrm{l}$ DNA and $9.5 \mu \mathrm{l}$ RNAse free water in micro tube. PCR condition was programed to pre-denaturation (at $95^{\circ} \mathrm{C}$ for 15 minutes); denaturation (at $94^{\circ} \mathrm{C}$ for 1 minute); annealing (at $53^{\circ} \mathrm{C}$ for 45 seconds); elongation (at $72^{\circ} \mathrm{C}$ for 1 minute); and postelongation (at $72^{\circ} \mathrm{C}$ for 10 minutes). The reaction was conducted as 32 cycles and the PCR product was then electrophoresed in the agarose gel $2 \%$ at 100 volt, 200
$\mathrm{mA}$ for 50 minutes and the desired result was $642 \mathrm{bp}$ under UV exposure or gelDoc camera (Lee at al. 2014).

\section{S rRNA gene sequencing}

Amplification products of $16 \mathrm{~S}$ rRNA were sent to $1^{\text {st }}$ Base Singapore to be sequenced using Sanget method.

\section{Data analysis}

Data of sequencing were analyzed using BIODET program to determine consensus and contig sequences, then blast nucleotide was done using BLASTn program (NCBI) to determine the identity structure and sequence homology resulted to other isolates in the GenBank. The sequence was compared to five highest isolates of BLASTn with multiple alignments using ClustalW program. Phylogenic tree was built using Neighbor joining program MEGA 7.0.25 method (Peng et al. 2017)

\section{RESULTS AND DISCUSSION}

Specific gene of $P$. multocide was detected using electrophoresing the PCR result of those five isolates in agarose gel. DNA of those five isolates was isolated using Qiagen ${ }^{\circledR}$ kit and then PCR was performed in accordance with the formula and condition described in the materials and methods. Amplification of specific gen $(\mathrm{kmt})$ of $P$. multocide using showed the amplicons at around of $460 \mathrm{bp}$ (Figure 1). It showed molecularly that those five isolates in this study were $P$. multocide. Solongo et al. (2015) performed genetic analysis of $P$. multocide isolated from local cattle of Mongolia and showed similar result. PCR condition was performed in accordance to the properties of forward and reverse oligonucleotide. Before the PCR process, melting temperature checking of forward and reserve primers was performed according to master mix that will be used in order to obtain the optimal result (Lorenz 2012).

Capsular gene of those five local isolates of $P$. multocide was detected using primer of CAPA and CAPB. Amplification result showed that two of five sample isolates were $P$. multocide serotype A that coded capsular gene A (PMa and PMc) showed with amplicons appearance at around 1044 base pair (Figure $2)$. Whereas, those three other isolates were isolate $P$. multocide serotype $\mathrm{B}$ ( $\mathrm{PMb}, \mathrm{PMd}$, and $\mathrm{PMk}$ ) that showed amplicons at 750 base pair (Figure 3 ). 


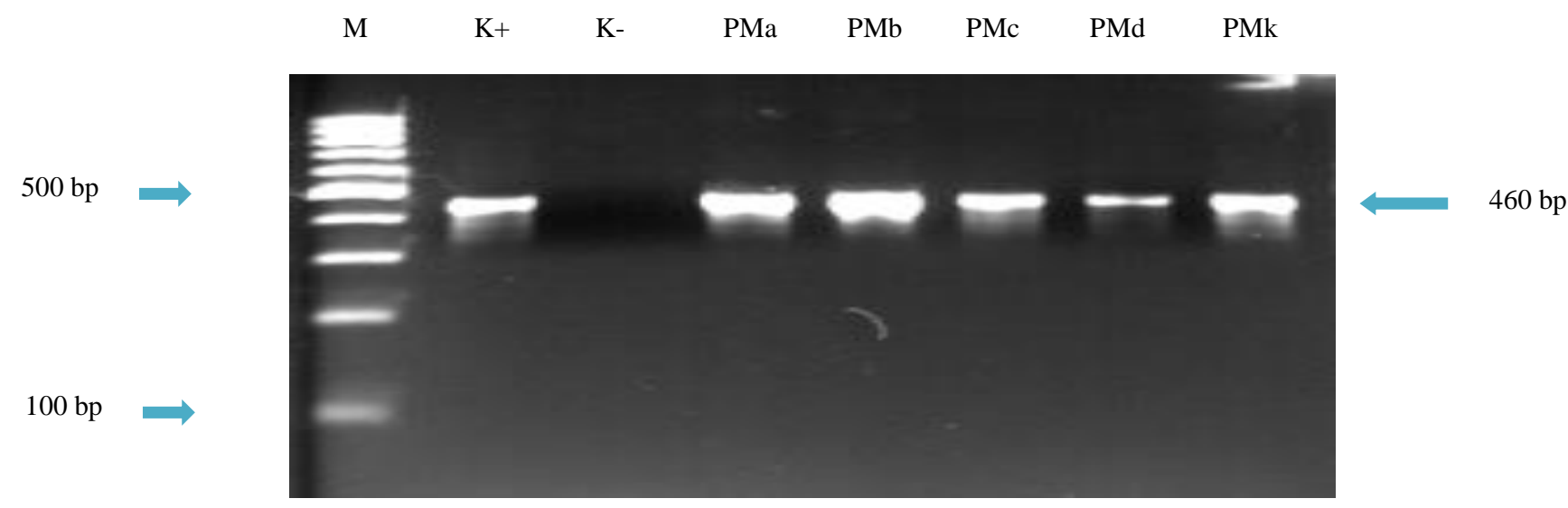

Figure 1. Detection of kmt gene of $P$. multocide using PCR.

PCR product of 460 base pairs (bp) specific to $P$. multocida

M: Marker, K+: Control positive (NCTC11668), K-: Control negative (B. abortus),

PMa, PMb, PMc, PMd: P. multocide Isolate from Lampung,

PMk: P. multocide Isolate from Kupang.

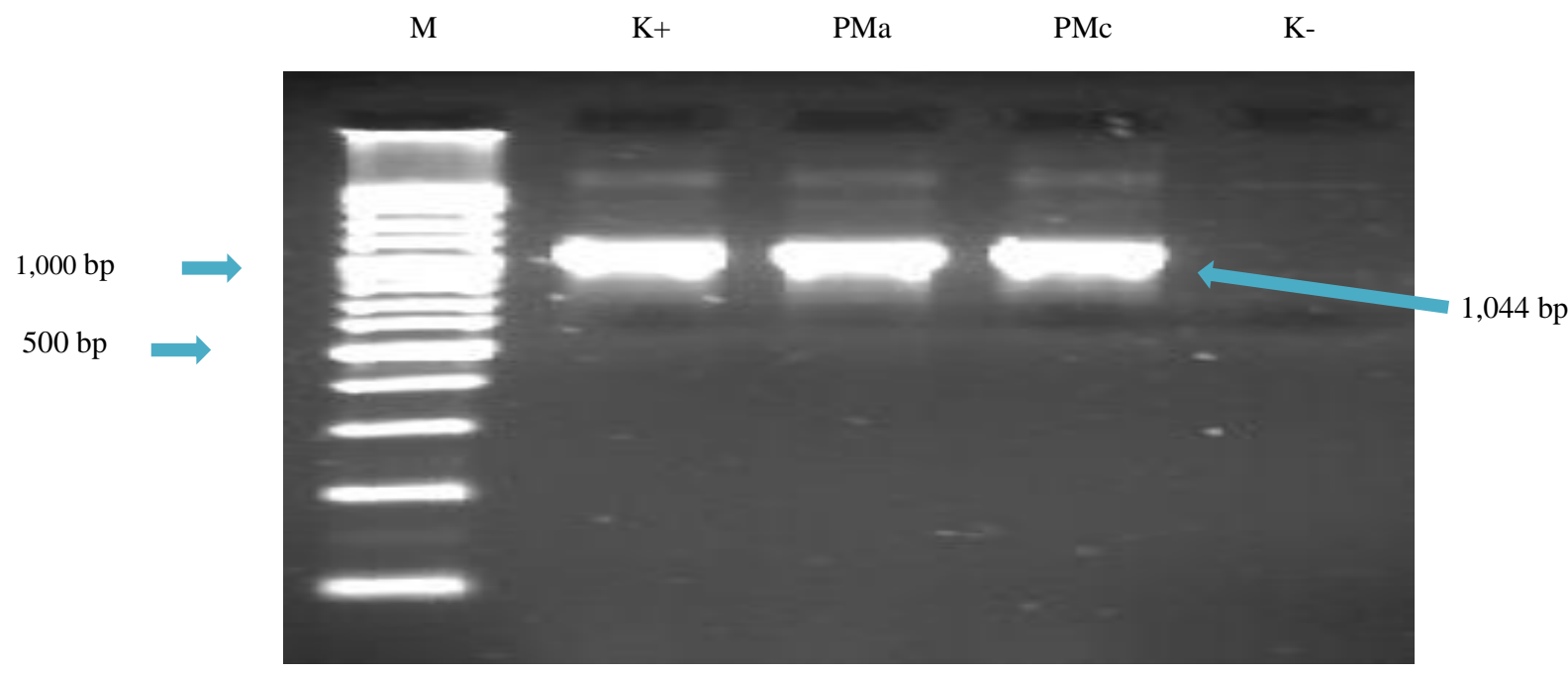

Figure 2. Detection of A capsular gene (hyaD-hyaC) of P. multocide using PCR. Amplicons of serotype $\mathrm{B}$ of $P$. multocide on around 1.044 base pairs (bps) M: Marker, K+: Control Positive (ATCC12945), K-: Kontrol Negative (B. abortus) PMa, PMc: $P$. multocide Isolate from Lampung.

The two PCR processes informed that $P$. multocide in this study were serotype A and B. all isolate samples from cattle in Lampung and Kupang. Serotype A on cattle generally related to pneumonia (Frank 1989), while the serotype B related to the hemorrhagic septicemia/HS (Ranjan et al. 2011). Kupang as the capital of East Nusa Tenggara province known as beef cattle production center in eastern Indonesia, is an endemic area of HS case or known as snoring disease. The snoring disease on cattle happens almost every year in Kupang (Berek et al. 2015) leading to decrease in cattle population in latest several years (Priyanto 2016). While the HS outbreak in South Lampung was reported in 1984 and 1989 (Putra 2006). However, this study has not been able to determine that $P$. multocide from Kupang always serotype B. It shows that it needed further studies with more samples from more area in East Nusa Tenggara, except Kupang.

Amplification of 16S rRNA gene using PCR method to $P$. multocide isolate was performed to determine the relationship of local $P$. multocide with several isolate from abroad. Subunit gene of ribosome 


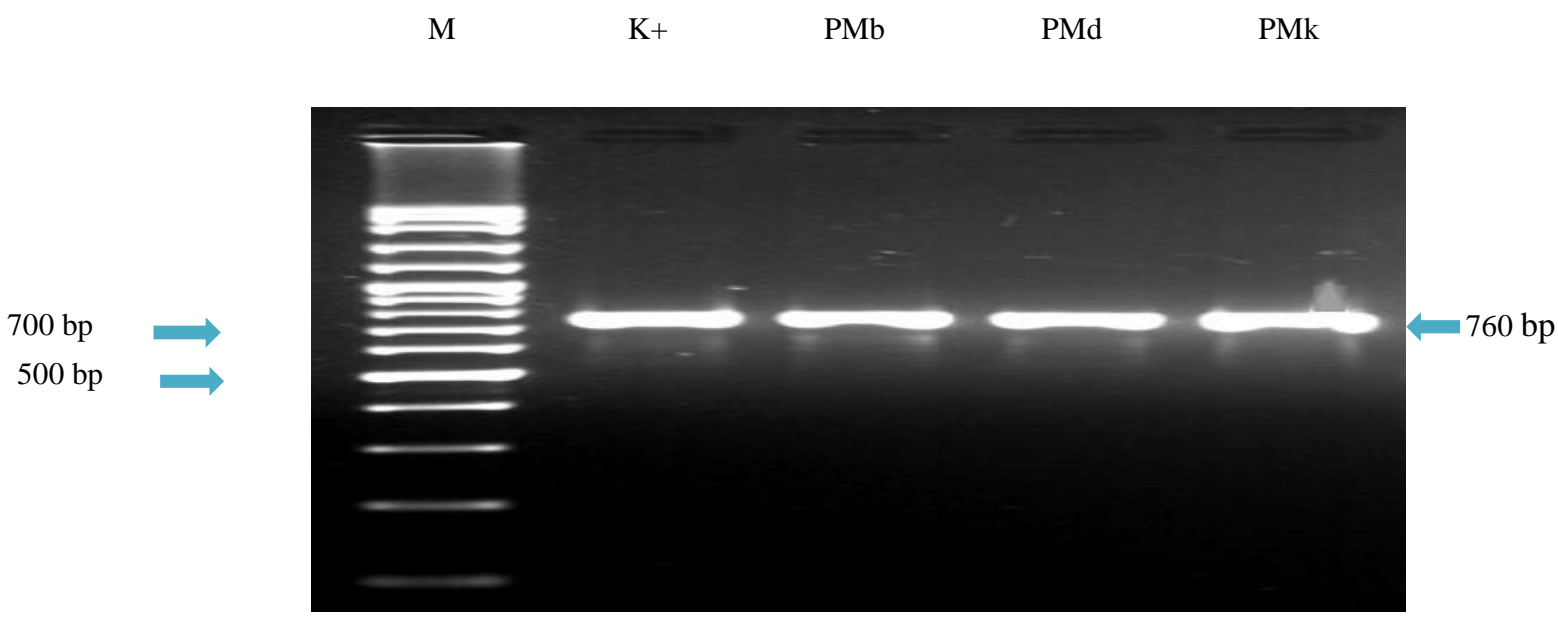

Figure 3. Detection of $\mathrm{B}$ capsular gene (bcbD) of $P$. multocide using PCR. Amplicons of B P. multocide serotype on around 760 base pairs (bps) M: Marker, K+: Control positive (NCTC11668), PMb, PMd: P. multocide Isolate from Lampung, PMk: P. multocide Isolate from Kupang.

16S (16S rRNA), especially has been widely used in studying and characterizing bacteria community coverage on various ecology including the host related to the community like human microbiome endogen (Arumugam et al. 2011a) or the host that unrelated to humans. rRNA sequence, especially $16 \mathrm{~S}$ rRNA represents the most important targets in the study of bacterial and ecological evolution, including to determine the phylogenic among taxa and exploration of environment bacteria diversity. The 16S rRNA gene was selected because that gene is distributed universally that allow phylogenic relationship analysis between the distant taxa (Větrovský \& Baldrian 2013).

The two PCR processes informed that $P$. multocide in this study were serotype A and B. all isolate samples from cattle in Lampung and Kupang. Serotype A on cattle generally related to pneumonia (Frank 1989), while the serotype B related to the hemorrhagic septicemia/HS (Ranjan et al. 2011). Kupang as the capital of East Nusa Tenggara province known as beef cattle production center in eastern Indonesia, is an endemic area of HS case or known as snoring disease. The snoring disease on cattle happens almost every year in Kupang (Berek et al. 2015) leading to decrease in cattle population in latest several years (Priyanto 2016). While the HS outbreak in South Lampung was reported in 1984 and 1989 (Putra 2006). However, this study has not been able to determine that $P$. multocide from
Kupang always serotype B. It shows that it needed further studies with more samples from more area in East Nusa Tenggara, except Kupang.

Amplification of 16S rRNA gene using PCR method to $P$. multocide isolate was performed to determine the relationship of local $P$. multocide with several isolate from abroad. Subunit gene of ribosome 16S (16S rRNA), especially has been widely used in studying and characterizing bacteria community coverage on various ecology including the host related to the community like human microbiome endogen (Arumugam et al. 2011a) or the host that unrelated to humans. rRNA sequence, especially $16 \mathrm{~S}$ rRNA represents the most important targets in the study of bacterial and ecological evolution, including to determine the phylogenic among taxa and exploration of environment bacteria diversity. The 16S rRNA gene was selected because that gene is distributed universally that allow phylogenic relationship analysis between the distant taxa (Větrovský \& Baldrian 2013).

Amplification result of $16 \mathrm{~S}$ rRNA gene of $P$. multocide local isolate was 642 base pairs (Figure 4) which then was sequenced and analyzed using BIODET program to determine the contig sequence. The BLASTn program on NCBI site was used to blast to determine isolate homolog to the other isolates at the GenBank. 


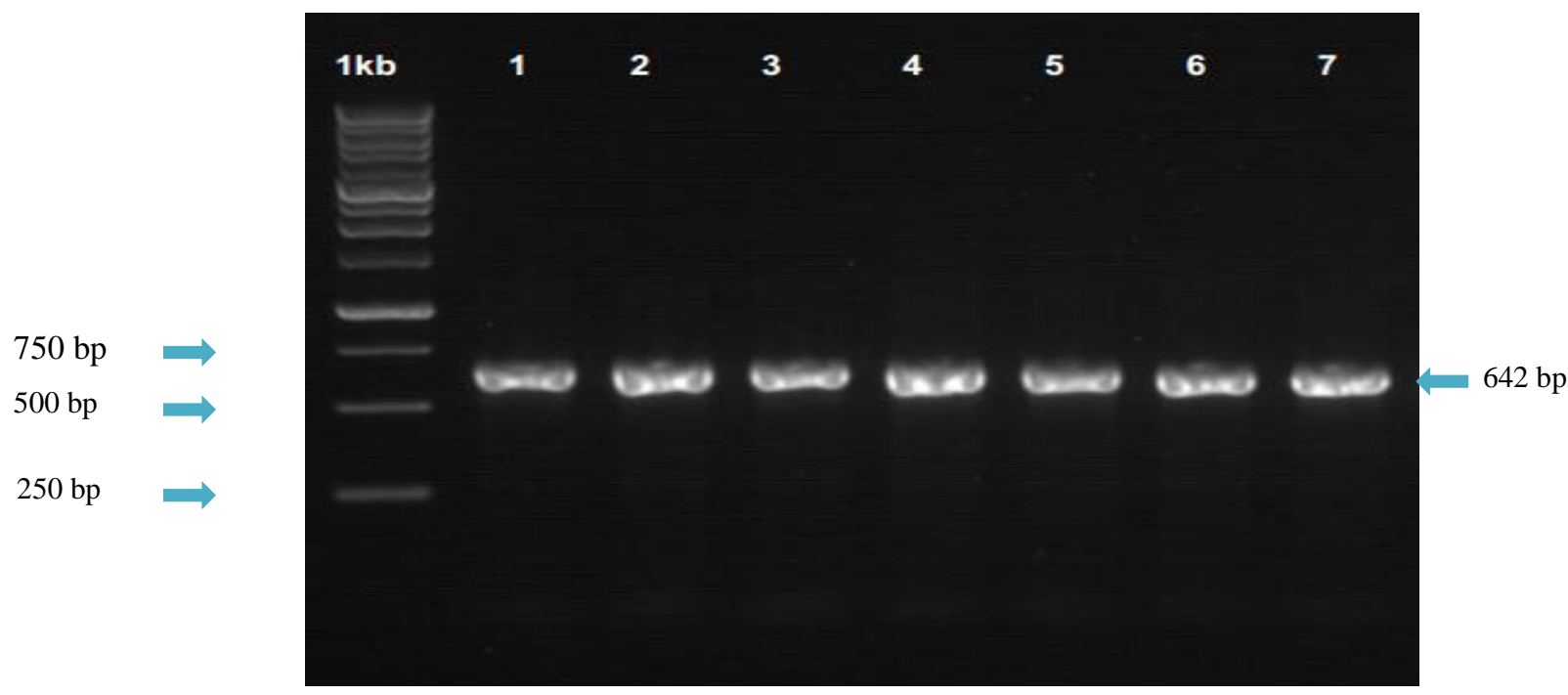

Figure 4. Detection of $16 \mathrm{~S}$ rRNA gene of $P$. multocida

Amplicons of 16S rRNA gen of $P$. multocide on around 642 base pairs (bps) 1kb: Marker, 1: NCTC11668, 2: ATCC12945

3: PMa, 4: PMb, 5: PMc, 6: PMd, (Isolate from Lampung) 7: PMk (Isolate from Kupang)

Table 1. Matrix of nucleotide difference (642 nucleotides) of 16S rRNA gene using MEGA 7.0.25 program

\begin{tabular}{|c|c|c|c|c|c|c|c|c|c|c|c|c|c|c|c|c|}
\hline Name & 1 & 2 & 3 & 4 & 5 & 6 & 7 & 8 & 9 & 10 & 11 & 12 & 13 & 14 & 15 & 16 \\
\hline \multicolumn{17}{|l|}{ PM_797_India } \\
\hline PM_FUP9_Egypt & 0.000 & & & & & & & & & & & & & & & \\
\hline PM_Japan & 0.000 & 0.000 & & & & & & & & & & & & & & \\
\hline PM_NCTC10322_Scotland & 0.000 & 0.000 & 0.000 & & & & & & & & & & & & & \\
\hline PM_GDZQ201401_China & 0.004 & 0.004 & 0.004 & 0.004 & & & & & & & & & & & & \\
\hline PM_TB2.1_Malaysia & 1.190 & 1.190 & 1.190 & 1.190 & 1213 & & & & & & & & & & & \\
\hline PM_Razi_Iran & 1.190 & 1.190 & 1.190 & 1.190 & 1213 & 0.000 & & & & & & & & & & \\
\hline PM_NCTC10322_Canada & 1.190 & 1.190 & 1.190 & 1.190 & 1213 & 0.002 & 0.002 & & & & & & & & & \\
\hline PM_ATCC12945 & 1.190 & 1.190 & 1.190 & 1.190 & 1213 & 0.002 & 0.002 & 0.000 & & & & & & & & \\
\hline PM_NCTC11668 & 1.190 & 1.190 & 1.190 & 1.190 & 1213 & 0.002 & 0.002 & 0.000 & 0.000 & & & & & & & \\
\hline PM_a_Lampung & 1.179 & 1.179 & 1.179 & 1.179 & 1.202 & 0.004 & 0.004 & 0.002 & 0.002 & 0.002 & & & & & & \\
\hline PM_b_Lampung & 1.179 & 1.179 & 1.179 & 1.179 & 1.202 & 0.004 & 0.004 & 0.002 & 0.002 & 0.002 & 0.000 & & & & & \\
\hline PM_c_Lampung & 1.190 & 1.190 & 1.190 & 1.190 & 1213 & 0.002 & 0.002 & 0.000 & 0.000 & 0.000 & 0.002 & 0.002 & & & & \\
\hline PM_d_Lampung & 1.190 & 1.190 & 1.190 & 1.190 & 1213 & 0.000 & 0.000 & 0.002 & 0.002 & 0.002 & 0.004 & 0.004 & 0.002 & & & \\
\hline PM_k_Kupang & 1.190 & 1.190 & 1.190 & 1.190 & 1213 & 0.000 & 0.000 & 0.002 & 0.002 & 0.002 & 0.004 & 0.004 & 0.002 & 0.000 & & \\
\hline Brucella_abortus & 0220 & 0.220 & 0.220 & 0.220 & 0.225 & 1.195 & 1.195 & 1.195 & 1.195 & 1.195 & 1.184 & 1.184 & 1.195 & 1.195 & 1.195 & \\
\hline
\end{tabular}

Description: PM: Pasteurella multocide; a,b,c,d, k: code for samples (local isolate). 


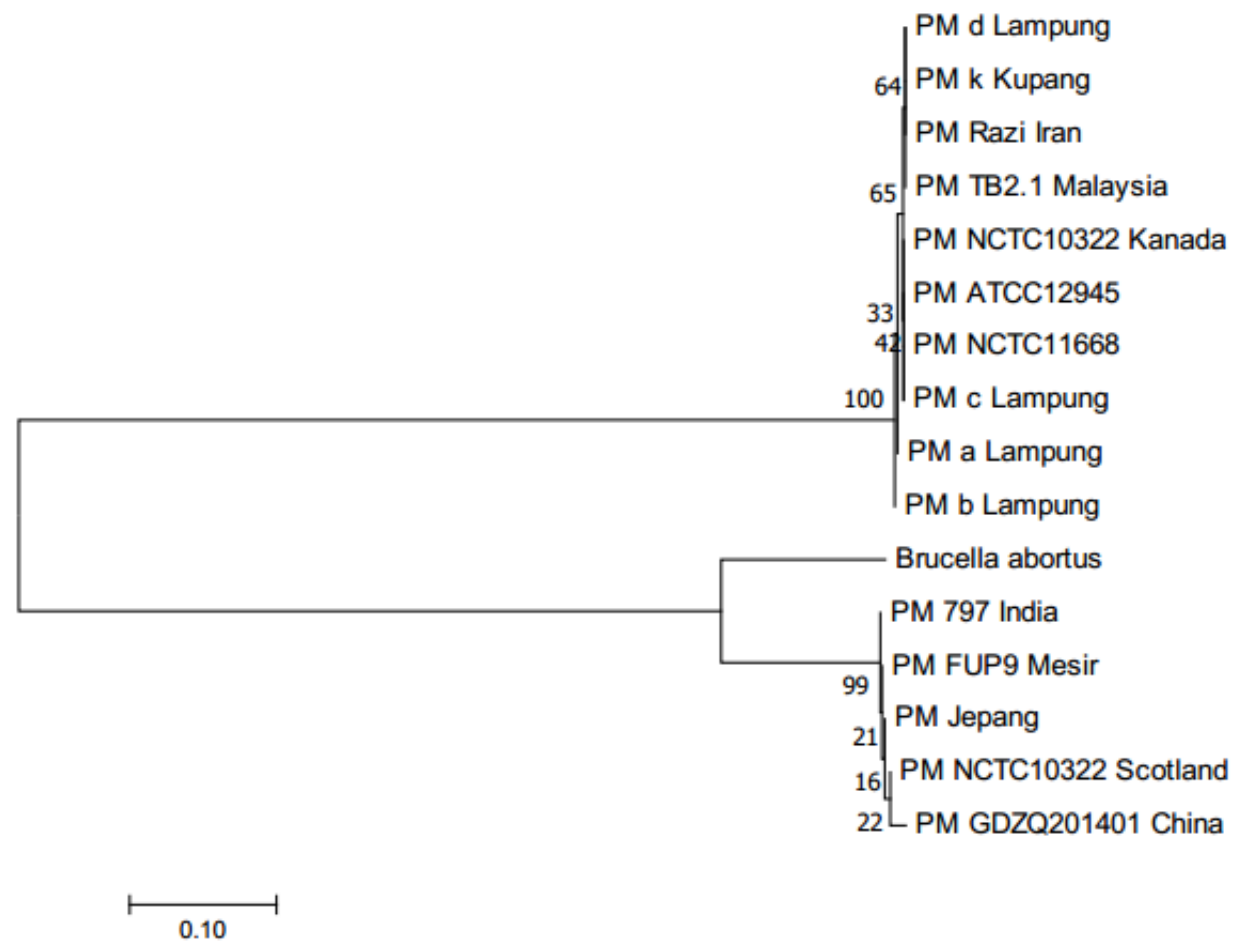

Figure 5. Phylogram of Evolutionary History of 16S rRNA (642 nt) gene nucleotide of local isolate P. mulcotide compared to isolates from other countries from GenBank using Neighbor-joining that counting by 2 parameters Kimura method on MEGA 7.0.25 program.

The multiple alignment of the sequence of $16 \mathrm{~S}$ rRNA gene nucleotide of $P$. multocide of sequencing resulted in this study with the sequencing from China, Japan, India, Scotland and Egypt from the GenBank using ClustalW program showed the existence of the nucleotide.

Genetic distance counting by 2 parameters Kimura method (Table 1) showed genetic distance difference between the P. multocide isolates from Lampung and Kupang and $P$. multocide isolates from several countries in the world. The average genetic distance between $P$. multocide species using neighbor joining method of 642 bases of nucleotides of the 16S rRNA gene showed that level of the nucleotide of $P$. multocide isolate in the results of the study have no relationship with isolates from India, Egypt, Japan, Scotland and China. P. multocide isolate from Lampung and Kupang had relationship with the $P$. multocide isolate from Malaysia, Iran and Canada (Figure 5).

Matrix value of the genetic distance between each isolate presented in Table 1 was used to build phenogram tree (Figure 5). That phenogram tree shows the genetic distance between all isolates. In other words, all $P$. multocide isolates aligned is divided into two main branches, so that the $P$. multocide isolate from Lampung and Kupang is in the same branch with the $P$. multocide from Malaysia, Iran, and Canada, Pascoe et al. (2017) said that genetic structure of bacteria population can be associated with geographical location of isolation. On several species, there is a strong correlation between geographic distance and genetic distance that may be caused by different evolutionary evolution. Sheppard et al. (2014) stated that frequency of certain genotype isolated from the different host is a basic of host identification related to clonal complex. This indicates that nucleotide sequence is different in two main groups of phenogram tree that shows the thing that may occur due to a different host, geographic and isolate. It does not rule out the possibility of the different nucleotide sequence was affected by lineage development due to deviations of a single or multiple genes on Multi Locus Sequence Typing gene (Bisgaard et al. 2013).

\section{CONCLUSION}

This study and analysis informed that five bacteria isolates have been identified as $P$. multocide serotype A and serotype B. Four isolates from Lampung consisted of each two isolates either serotype A or serotype B. While, isolates from Kupang was P. multocide serotype B. PMc isolate had high homologue with the ATCC 12945 , so that it can be used as positive control of serotype A. On the other hand, P. multocide isolate 
from Kupang can be used as positive control of serotype $\mathrm{B}$, because it is identic to $P$. multocide PMTB2.1 (CP007205.2) isolated from buffalo infected with HS in Malaysia.

\section{ACKNOWLEDGEMENT}

We thank Indonesian Agency for Agricultural Research and Development, Ministry of Agriculture that financed this study. We also appreciate the Head of Indonesian Research Center for Veterinary Science who facilitated during this study conducted; Head of Veterinary Institute of Lampung and Head of Laboratory of Animal Health Type C of Kupang District who facilitated the isolation of $P$. multocide bacteria.

\section{REFERENCES}

Arumugam M, Raes J, Pelletier E, Le Paslier D, Yamada T, Mende DR, Fernandes GR, Tap J, Bruls T, Batto JM, Bertalan M, Borruel N, Casellas F, Fernandez L, Gautier L, Hansen T, Hattori M, Hayashi T, Kleerebezem M, Kurokawa K, Leclerc M, Levenez F, Manichanh C, Nielsen HB, Nielsen T, Pons N, Poulain J, Qin J, Ponten TS, Tims S, Torrents D, Ugarte E, Zoetendal EG, Wang J, Guarner F, Pederson O, de Vos WM, Brunak S, Dore J, Consortium M, Weissenbach J, Ehrlich SD, Bork P. 2011a. Enterotypes of the human gut microbiome. Nature. 473:174-180.

Arumugam ND, Ajam N, Blackall PJ, Asiah NM, Ramlan M, Maria J, Yuslan S, Thong KL. 2011b. Capsular serotyping of Pasteurella multocide from various animal hosts - a comparison of phenotypic and genotypic methods. Trop Biomed. 28:55-63.

Berek HSD, Nugroho WS, Wahyuni AETH. 2015. Protektivitas sapi di Kabupaten Kupang terhadap penyakit ngorok (Septicaemia Epizootica). J Vet. $16: 167-173$.

Bisgaard M, Petersen A, Christensen H. 2013. Multilocus sequence analysis of Pasteurella multocide demonstrates a type species under development. Microbiology. 159:580-590.

De Oliveira FJX, Mores MAZ, Robelatto R, Agnol AMD, Plieski CLA, Klein CS, Barcellos DESN, Mores N. 2015. Pasteurella multocida type A as the primary agent of pneumonia and septicaemia in pigs. Pesq Vet Bras. $35: 716-724$.

Dziva F, Muhairwa AP, Bisgaard M, Christensen H. 2008. Diagnostic and typing options for investigating disease associated with Pasteurella multocide. Vet Microbiol. $128: 1-22$

El-Jakee JK, Ali SS, El-Shafii SA, Hessain AM, Al-Arfaj AA, Mohamed MI. 2016. Comparative studies for serodiagnosis of haemorrhagic septicaemia in cattle sera. Saudi J Biol Sci. 23:48-53.
Frank GH. 1989. Pasteurellosis of cattle. In: Adlam C. Rutter JM. Editors. Pasteurella and Pasteurellosis. London (UK): Academic Press. p. 197-222.

Furian TQ, Borges KA, Pilatti RM, Almeida C, Nascimento VP do, Salle CTP, Moraes HL de S. 2014. Identification of the capsule type of Pasteurella multocide isolates from cases of fowl cholera by Multiplex PCR and comparison with phenotypic methods. Braz J Poult Sci. 16:31-36.

Kim CJ, Nagaraja KV. 1990. DNA fingerprinting for differentiation of field isolates from reference vaccine strains of Pasteurella multocide in turkeys. Am J Vet Res. 51:207-210.

Kimura M. 1980. A simple method for estimating evolutionary rate of base substitutions through comparativemstudies of nucleotide sequences. J Mol Evol. 16:111-120.

Kubatzky KF. 2013. Pasteurella multocide and immune cells. Curr Top Microbiol Immunol. 361:53-72

Kumar S, Stecher G, Tamura K. 2016. MEGA7: Molecular Evolutionary Geneticts Analysis version 7.0 for bigger datasets. Mol Biol Evol. 33:1870-1874.

Lee DJ, Kim SY, Kim JD, Kim YS, Song HJ, Park CY. 2014. Reducing the number of UVB lamps for low-cost gel imaging system implementation. Int $\mathrm{J}$ Control Automation. 7:33-42.

Liu H, Zhao Z, Xi X, Xue Q, Long Ta and Xue Y. 2017. Occurrence of Pasteurella multocide among pigs with respiratory disease in China between 2011 and 2015. Ir Vet J. 70:2.

Lorenz TC. 2012. Polymerase Chain Reaction: Basic protocol plus troubleshooting and optimization strategies. J Vis Exp. 63:3998.

Magyar T, Donko T, Repa I, Kovacs M. 2013. Regeneration of toxigenic Pasteurella multocide induced severe turbinate atrophy in pigs detected by computed tomograph. BMC Vet Res. 9:222.

Mizrahi-Man O, Davenport ER, Gilad Y. 2013. Taxonomic classification of bacterial 16S rRNA genes using short sequencing reads: Evaluation of effective study designs. PLoS ONE. 8:e53608.

Moustafa AM, Seeman T, Gladman S, Adler B, Harper M, Boyce JD, Bennett MD. 2015. Comparative genomic analysis of Asian haemorrhagic septicaemia-associated strains of Pasteurella multocide identifies more than 90 Haemorrhagic septicaemia-specific genes. PLoS ONE. 10:e0130296.

Mutters R, Ihm P, Pohl S, Frederiksen W, Mannheim W. 1985. Reclassification of genus Pasteurella trevisan 1887 on the basis of deoxyribonucleic acid homology, with the proposals for the new species Pasteurella dagmatis, Pasteurella cannis, Pasteurella stomatis, Pasteurella anatis, and Pasteurella langaa. Int $\mathbf{J}$ Systematic Bacteriol. 35:309-322. 
Pascoe B, Meric G, Yahara K, Wimalarathna H, Murray S, Hitchings MD, Sproston, EL, Carrillo CD, Jolley KA, Maiden MCJ, McCarthy ND, Didelot X, Parker CT, Sheppard SK. 2017. Local genes for local bacteria: Evidence of allopatry in the genomes of transatlantic Campylobacter populations. Mol Ecol. 26: 4497-4508.

Peng Z, Liang W, Wang Y, Liu W, Zhang H, Yu T, Zhang A, Chen H, Wu B. 2017. Experimental pathogenicity and complete genome characterization of a pig origin Pasteurella multocide serogroup $\mathrm{F}$ isolat HN07. Vet Microbiol. 198:23-33.

Priyanto D. 2016. Strategi Pengembalian wilayah Nusa Tenggara Timur sebagai sumber ternak sapi potong. J Litbang Pertanian. 35:167-178.

Putra AAG. 2006. Situasi penyakit hewan menular strategis pada ruminansia besar: Surveilans dan Monitoring. Prosiding Lokakarya Nasional Ketersediaan IPTEK dalam Pengendalian Penyakit Stategis pada Ternak Ruminansia Besar. Bogor (Indones): Indonesian Center for Animal Research and Development. p. 31-49.

Ranjan R, Panda SK, Acharya AP, Singh AP, Gupta MK. 2011. Molecular diagnosis of Haemorrhagic Septicaemia - A Review. Vet World. 4:189-192.

Shayegh J, Sharaf JD, Mikaili P. Namvar H. 2009. Pheno-and genotyping of Pasteurella multocide isolated from goat in Iran. Afr J Biotechnol. 8:3707-3710.

Sheppard SK, Cheng L, Meric G, de Haan CP, Llarena AK, Marttinen P, Vidal A, Ridley A, Clifton-Hadley F,
Connor TR, Strachan NJ, Forbes K, Colles FM, Jolley KA, Bentley SD, Maiden MC, Hanninen ML, Parkhill J, Hanage WP, Corander J. 2014. Cryptic ecology among host generalist Campylobacter jejuni in domestic animals. Mol Ecol. 23:2442-2451.

Solongo E, Batbaatar V, Enkhtuul B, Lundaa Ts, Khulan J, Erdenebaatar J. 2015. Result on genetic analysis of Pasteurella multocide isolated from Local Mongolian Cattle. J Agric Sci. 15:22-26.

Thornton B, Basu C. 2011. Real-time PCR (qPCR) primer design using free online software. Biochemist Mol Biol Education. 39:145-154.

Townsend KM, Boyce JD, Chung JY, Frost AJ, Adler B. 2001. Genetic organization of Pasteurella multocide cap Loci and development of a multiplex capsular PCR typing system. J Clin Microbiol. 39:924-929.

Townsend KM, Hanh TX, O'Boyle D, Wilkie I, Phan TT, Wijewardana TG, Trung NT, Frost AJ. 2000. PCR detection and analysis of Pasteurella multocide from the tonsils of slaughtered pigs in Vietnam. Vet Microbiol. 72:69-78

Větrovský T, Baldrian P. 2013. The variability of the $16 \mathrm{~S}$ rRNA gene in bacterial genomes and its consequences for bacterial community analyses. PLoS ONE. 8:e57923

Wilson BA, Ho M. 2013. Pasteurella multocide: from Zoonosis to cellular microbiology. Clin Microbiol Rev. 26:631-655. 